\title{
China-U. S. A Trade Friction on Bilateral Trade
}

\author{
Most. Ayasha Siddiqua \\ Assistant Professor \\ Department of Management Studies, Begum Rokeya University, Rangpur, Bangladesh
}

\begin{abstract}
This study is typically descriptive in nature that has been analyses through different componential data of the Chinse and U.S.A economy about the bilateral trade issues. The objective of the paper is to analyze and find the friction areas of Chinese and USA trade and implications. U.S.A-China change friction is dampening the Chinese financial system, particularly through a decline in the call for. Over the medium to a long time, the alternate row should depress China's capability economic growth price via supply-aspect elements., the united states are strengthening regulations on acquisitions of U.S. excessive-tech companies by means of Chinese businesses. This, mixed with strengthened capital manage in China, has brought about a steep decline in Chinese direct investments inside America, from 46 billion bucks in 2016 to 29 billion dollars in 2017 and to 4.8 billion dollars in appearing time will make it more and more tough for China to acquire technology and others from the U.S.A. China and America have discovered bilateral treaties and multilateral regulations which includes the WTO guidelines, economic and trade family members have grown deeper and wider. comparative strengths and the picks of the market, the two international locations have constructed up a jointly useful courting proposing structural synergy and convergence of interests., a few stages of change friction are handiest herbal. the key, however, lies in a way to beautify mutual trust, promote cooperation, and manage variations. principle of resolving disputes thru talk and session, and answering U.S issues with the best stage of staying power and true religion. It has triumphed over many problems and made giant efforts to stabilize China-US economic and change family members via preserving rounds of discussions with the facet of the united states and providing sensible solutions. however, the USA aspect has been contradicting itself and constantly hard in China. As a result, change and economic friction among the two aspects has escalated quick over a short period of time, causing critical damage to the economic and alternate family members that have developed over time thru the collective work of the two governments and the two peoples, and posing a grave risk to the multilateral buying and selling system and the principle of unfastened trade and economics.
\end{abstract}

Keywords: Trade, Implications, Friction. Bilateral

DOI: $10.7176 / \mathrm{IAGS} / 86-02$

Publication date:September $30^{\text {th }} 2020$

\section{Introduction}

China is the largest developing country in addition to therefore U. S. It is that the biggest developed country in the context of the world economy, Friedber A. L. (2005). Trade and economic relations stuck between China and therefore the US are of nice significance for the countries yet as for the steadiness in addition to the development of the world economy. Woo, W. T. (2008) studied that subsequently, the institution of diplomatic relations, bilateral trade in addition to economic connections between China and therefore the US have developed steadily. A detailed partnership has ten solids beneath that interests of the two countries became nearer also wider. Each country has benefited from this partnership, as the remainders of the planet. Meanwhile, the start of the new century especially, aboard fast progress in economic development, China and therefore the US have determined bilateral tr ties in addition to tetramerous rules like the international organization rules, as well as economic and trade relations have adult deeper and wider. Giving support their comparative strengths and therefore the selections of the market, the two countries have designed up a mutualist relationship that includes structural activity and convergence of interests. Johnson, R. C. (2014) reveal that barred cooperation and economic complementarity between China and therefore America have boosted economic process, industrial upgrading as well as structural optimization $n$ in each country, and at constant time increased the potency and effectiveness of world worth chains, reduced production prices, offered bigger product selection, and generated huge profit for businesses and customers in each countries.

\section{The Rationale of the Study}

David, H., et al (2013) studied that China and therefore America are at totally different stages of development. They need totally different economic systems. So, some level of trade friction is merely natural. The key but in in the way to improve mutual trust, stimulate cooperation, as well as succeed variations. Within the spirit of equality, rationality, in addition moving to fulfill one another halfway, one-two countries have got wind of variety of communication as well as harmonization mechanisms like the Joint Commission on Commerce also Trade, the Strategic plus Economic Dialogue, and therefore the Comprehensive Economic Dialogue. Everything has created 
tremendous efforts to beat every kind of difficulties and changing economic and trade relations onward, that has served because of the ballast and mechanical device of the general bilateral relationship. In the meantime, taking the geographic point in 2017, the newly formed administration of the US Government has declared "America First". So, it's unrestricted the fundamental norms of mutual respect as well as equal consultation that escort negotiation. Moderately, it's overtly expounded philosophy, economic policy plus the economic form of government, creating false allegations against several countries in addition to regions - notably China - daunting different countries over and done with economic actions like imposing tariffs, in addition to making an attempt to foist its own interests on China through extreme burden China has retorted from the angle of the common interests of each party moreover because of the world trade order. It's observant the principle of resolving disputes concluded with dialogue and consultation, and responsive the U.S. issues with the best level of patience and straightness. The Chinese aspect has been handling these variations with the associate perspective of looking basis whereas dropping divergence. It overcomes several difficulties plus created huge purposes to stabilize China-U.S economic plus trade relations through plotting rounds of discussions with the U.S. aspect in addition to proposing sensible solutions. But the U.S. aspect has been denying itself and perpetually difficult China. For that instances, trade plus economic friction flanked by the 2 sides has accelerated rapidly over a brief amount of your time, inflicting serious injury to the economic plus trade relations that have established over the years through the cooperative work of 2 the governments as well Therefore the two peoples, then movement has a vital warning to the many-sided mercantilism system and therefore the principle of trade. In the way to elucidate the facts regarding China-US economic plus trade relations, make clear China's stance on trade friction with the U.S., and track affordable solutions, the govt. of China is publication this report. Economic cooperation stuck between the 2 countries is thus large, essential's well as broad-based, with such a large number of players, that it's expected for a few variations plus friction to emerge. The two countries ought to proceed a broad perspective, confine mind their strategic interests and therefore the international order, properly handle their variations by seeking basis 9ereas shelving variations, as well as take sensible steps to decide their tensions. An impartial valuation of the China-U.S. trade gap needs a complete and in-depth study, instead of a look at the deficit in merchandise. It's not China's goal to own a trade surplus. Somewhat, the quantitative relation of China's accounting surplus to its value has declined from $11.3 \%$ in 2007 to $1.3 \%$ in 2017.Morrison. W. M. (2011) found out the imbalance of interchange merchandise between China and therefore the US is a lot of a natural outcome of voluntary decisions the US has created in its economic structure and market in lightweight of its comparative strong point. To resolve this issue, either side ought to create joint efforts in restructuring. The US turns a blind eye to varied factors in its trade as well as economic cooperation with China, singles out the disparity of interchange merchandise and blames China for the imbalance that is partial and irrational. In today's world of larger economic process and extensive global production, bilateral trade plus economic rt) operation already encompass on the far side interchange merchandise. Interchange services as well as sales of native subsidiaries within the host country ought to even be enclosed. If we have. a tendency to provide full thought to those three factors - trade-in merchandise, interchange services than sales of native subsidiaries within the host country - trade and economic cooperation deliver balanced advantages normally for China and therefore the US, with the latter reaping a lot of web advantages.

\section{Objectives of the Study}

The gap in China-U.S. interchange merchandise could be a natural outcome of the U.S economic structure and results of the two countries' comparative strengths and therefore the international division of labor. The persistent and growing gap in interchange merchandise between the two countries could be a result of a variety of things, instead of China's intent. The objectives of the study are as follows

- The prospect of China-US trade friction on China-US bilateral trade.

- The Impact of China-US trade friction on China-US bilateral trade.

\section{Literature Review}

China-U. S economic relations have expanded well over the past three decades, their mutual total merchandise trade rose from $\$ 2$ billion in 1979 to $\$ 579$ billion in 2016. China now could be the U.S.' second-largest merchandise commercialism partner, third-largest export market, and largest supplier of imports. China-U.S. mutual trade and investment relations profit in each country, the USA provides China a giant exportation market, and therefore the USA imports of the lower-cost product from China greatly profit U.S. consumers. China is additionally the secondlargest foreign holders of U.S. Treasury securities, that helps the U.S. to stay interested rates low (Morrison, 2017). Despite growing economic relations and mutual dependence, China and therefore the U.S. bilateral disputes became progressively intensive. China criticizes the U.S. of their export restrictions on engineering product, their unfair treatments of China's free enterprise standing, and unreasonable trade sanctions on China. Major areas of concern expressed by the U.S. embody massive numbers of trade surplus, the comparatively ineffective record of imposing material possession rights (IPR), discriminatory innovation policies, and mixed record on implementing international organization obligations. Though two-faced with step by step increasing industrial disputes, the 
China-US economic relations square measure positive and develop quickly generally. However, the harmonious scenario looks to vary when Donald Trump's elective to be the president of the U.S.

Trump administration officers contend that the U.S. ought to take a lot of aggressive stance against China's trade ivies. Within the presidential election amount, Trump claimed to levy forty-fifth correctional tariffs on imports from China, and levy thirty-fifth correctional tariffs on imports from North American nation. when Trump formally became the president, though severe trade wars have not happened, however, trade dialogue within the fields of adjusting trade imbalance and exchange rate had already in the method. The china-U.S.A trade war isn't simply a threat by Trump, it's going to occur in some conditions within the future. Albeit the furious trade war between China and therefore the U.S. won't happy, researches on the consequences of attainable trade wars square measure still valuable and attention-grabbing within the perspective. Supported these backgrounds, this paper numerically explores UN agency will win the attainable China-US trade war with the methodology of process general equilibrium (CGE) modeling and simulation. The literature on China-US trade wars square measure restricted and are principally analytical. Dickenson (2017) analyses the chances of China-U.S. trade war at the moment stage. Lazard (2017) explores the China-U.S. relations within the Trump era from the rising market perspective. This paper points out that Trump has started a temperament to slap a forty-five tariff on foreign Chinese product and label China a currency manipulator for suppressing the worth of the renminbi to spice up its exports, and therefore the paper assumes the power of the U.S. to impose such a tariff and therefore the edges of doing, therefore, square measure questionable. Morrison (2017) studies China-U.S. trade and investment relations comprehensively and analyses attainable bilateral trade wars. Hughes and Meckling (2017) discuss the US-China star dispute. Orville and Chairs (2017) analyses the USA policy toward China and provides recommendations for a brand-new administration. There are enumerable analysis papers exploring the consequences of China-US trade wars by trial and error.

Dong and Whalley (2012) use too closely connected numerical general equilibrium models of world trade to research the potential consequences of US-China bilateral revenge on trade flows and welfare. Results counsel that revenge between the two countries may be welfare rising for the USA because it substitutes expenditures into own product and improves its terms of trade, whereas China could also be adversely affected. Gompert et al. (2016) explore the potential China-US wars of their military losses, economic prices, political effects, and international effects. Li (2017) uses a numerical general equilibrium methodology to explore the consequences of bilateral trade revenge on China, our simulation results counsel that China is going to be a hint by trade revenge. However, the background of those existing researches isn't this scenario of China-US trade war at Trump era.

\section{Research Methodology}

The study objective is finding out the impact of China-US trade friction on China-US bilateral trade.it has been used different data from UNCTAD and WDI, different published articles, etc. The analyses the data for international trade within these two countries. It has been used basically export-import and trade-economic data within these two countries

\section{Result and Findings}

Mutually-beneficial and win-win cooperation between China and the US in trade and economy Economic and trade relations have developed steadily since the institution of diplomatic ties between China and also the United States, with fruitful results achieved in trade and investment. China edges remarkably from the sturdy action, whereas the United States conjointly reaps in-depth economic edges from the opportunities and results generated by China's growth. It's axiomatic that a sound China-US economic and trade relationship is extremely vital for each country. Cooperation serves the interests of the 2 sides and conflict will solely hurt each.

- China and also the United States are vital partners for every alternative in trade merchandise.

Two-way trade merchandise has matured speedily. Chinese statistics show that trade merchandise between China and also the United States in 2017 amounted to US\$583.7 billion, a 233-fold increase from 1979 once the two countries cast diplomatic ties, likewise as a seven-fold increase from 2001 once China joined the globe Trade Organization. Currently, the United States is China's biggest export market and the sixth biggest supply of imports. In 2017, the United States took nineteen of China's exports and provided V-day of China's imports. China is the quickest growing export marketplace for United States Mirandize and also the biggest supply of imports of the US. In 2017, V-day people exports visited China.

US exports to China are growing abundant quicker than their world average. Since its accession to the World Trade Organization, China has become a crucial marketplace for United States exports, that have matured speedily. International organization statistics indicate that in 2017 United States exports of products to China amounted to US $\$ 129.89$ billion, $577 \%$ increase from US\$19.18 billion in 2001, and much on top of the one $2 \%$ average rate of growth of overall United States exports show in Figure 1. 
Figure 1: US Exports to China Grow Faster than its Global Export Trade (\%)

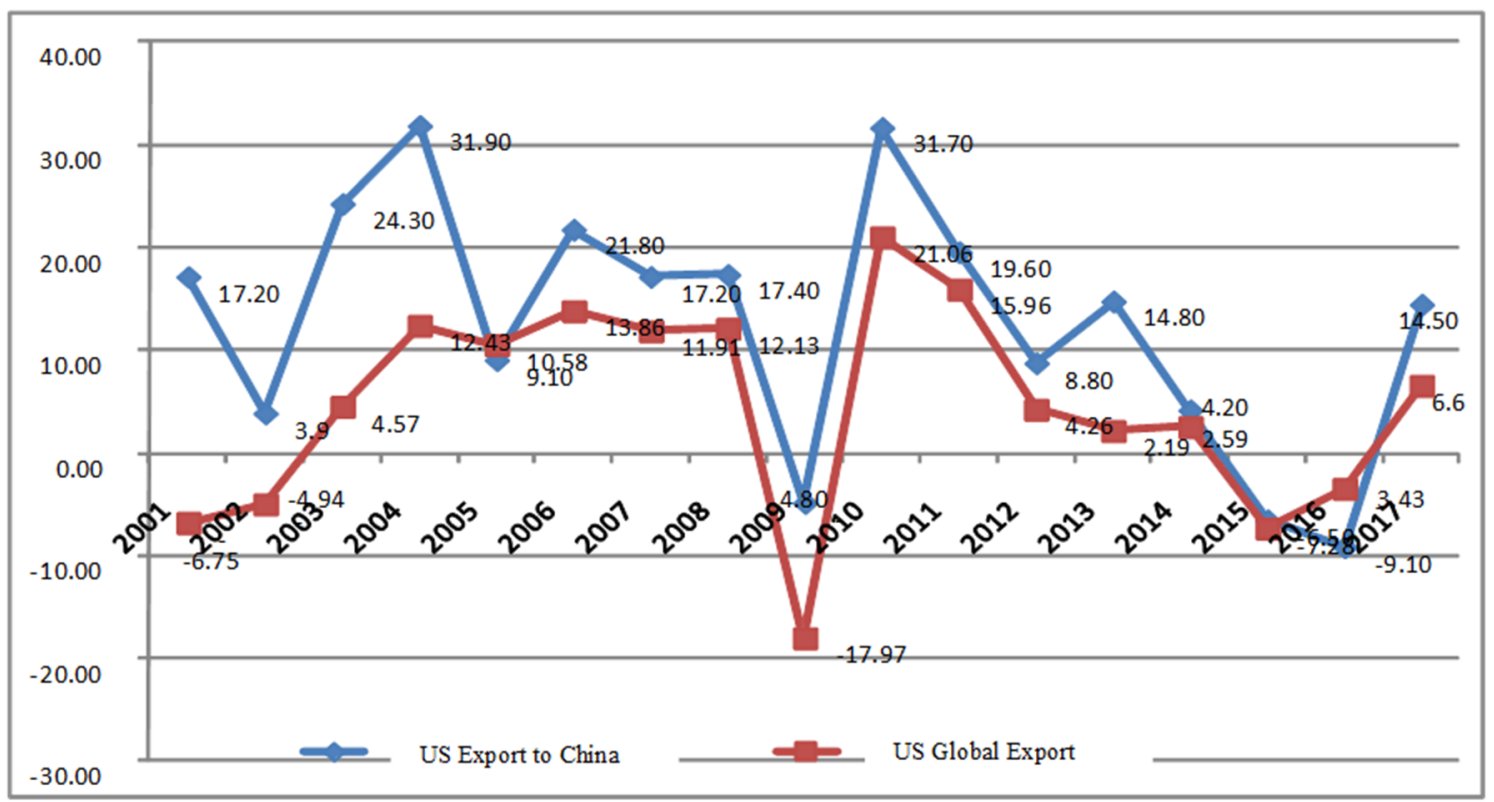

\section{Source: UNCTAD}

- Bilateral trade in services is developing quickly.

The United States features a highly-advanced and fully-fledged industry that is extremely competitive on the international market. Related to the expansion of the Chinese economy and also the improvement of Chinese people's living standards is a noticeable rise in demand for services and zoom in bilateral services trade. In line with United States statistics, two-way trade services rose from US\$24.94 billion in 2007 to US\$75.05 billion in 2017. In line with MOFCOM, the United States was China's second-biggest services trade partner; in line with USDOC, China is that the third biggest marketplace for United States service exports. The United States is the biggest supply of China's deficit in services trade and this deficit has been increasing quickly. United States statistics show that United States service exports to China grew 340\% from US\$13.14 billion in 2007 to US\$57.63 billion in 2017 whereas its service exports to alternative countries and regions within the same amount grew by one hundred and eightieth. The Lilted States surplus with China in services increased by an element of thirty to the United States forty.2 billion. (Chart 2) at present, the United States represents roughly two-hundredth of China's total deficit in services trade, the most important supply of this deficit. China's deficit with the United States is focused on 3 areas, travel, and transport and material possession royalties.

Figure 2: US Services Imports from and Exports to China (unit: US\$100 MN)

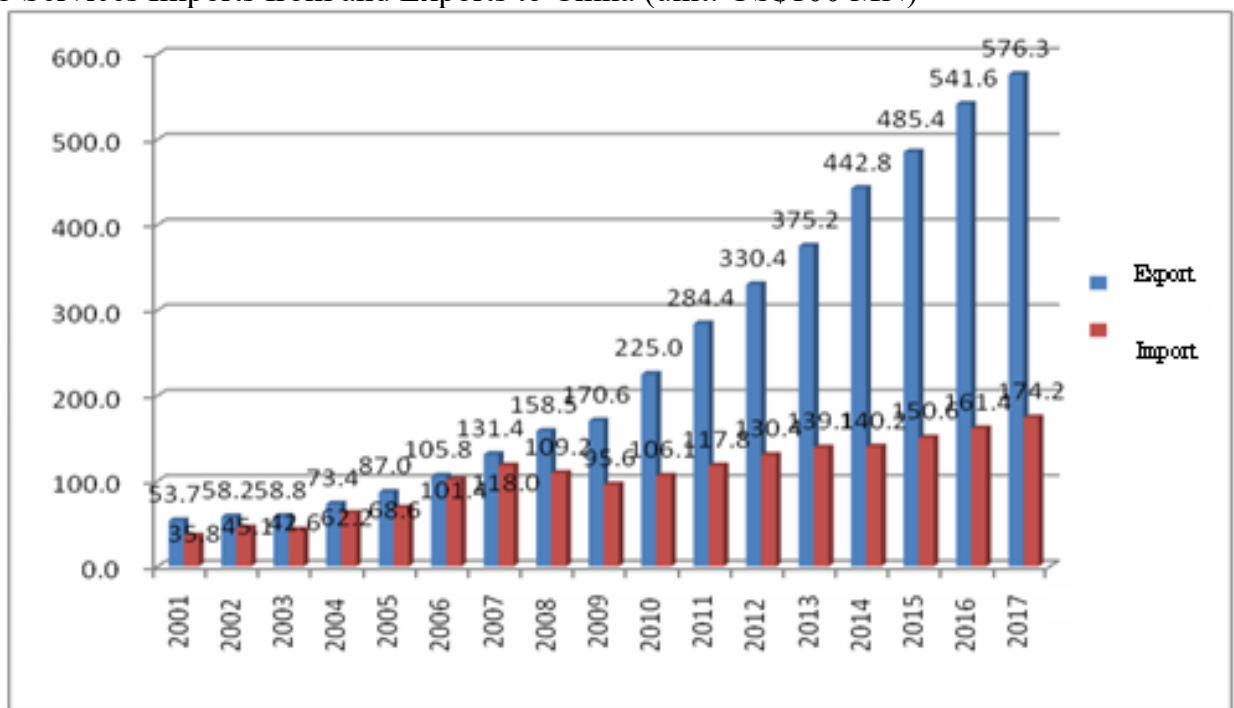

Source: Bureau of Economic Analysis, U.S DOC

China's change deficit with the united states in tourism maintains to widen. in step with the doc, by 2016 the variety of Chinese language mainland visitors to the united states had been increasing for 13 consecutive years, 
with double-digit growth in 12 of the thirteen years. MOFCOM facts advocate that in 2017 Chinese language site visitors going to the united states for tourism, education, and medical treatment spent a complete of US\$51 billion in the U.S. amongst them, three million have been tourists, who spent as a whole lot as US\$33 billion while journeying within the US. In education, the united states are the most important overseas destination for Chinese college students. In 2017, there had been round 420,000 Chinese language students inside the US, contributing some US\$18 billion to nearby revenues. in step with U.S figures, China's change deficit with the united states in tourism grew from US\$430 million in 2006 to US\$26.2 billion in 2016, registering an average annual increase of $50.8 \%$. China's bills for the usage of US intellectual assets keeps to upward thrust. Chinese language information implies that U.S.Ais the biggest source of highbrow property imports to China. From 2012 to 2016, China imported almost 28,000 objects of intellectual property from America. China's payments for US intellectual assets doubled in six years from US\$three.46 billion in 2011 to US\$7.2 billion in2017. (Chart three) In breakdown, China's intellectual assets payments to the U.S.A accounted for $1 / 4$ of its overall intellectual belongings bills to overseas nations.

Figure 3: China's Payment for the Use of US Intellectual Property

\section{China's Payment for the Use of US Intellectual Property (US\$100 million)}

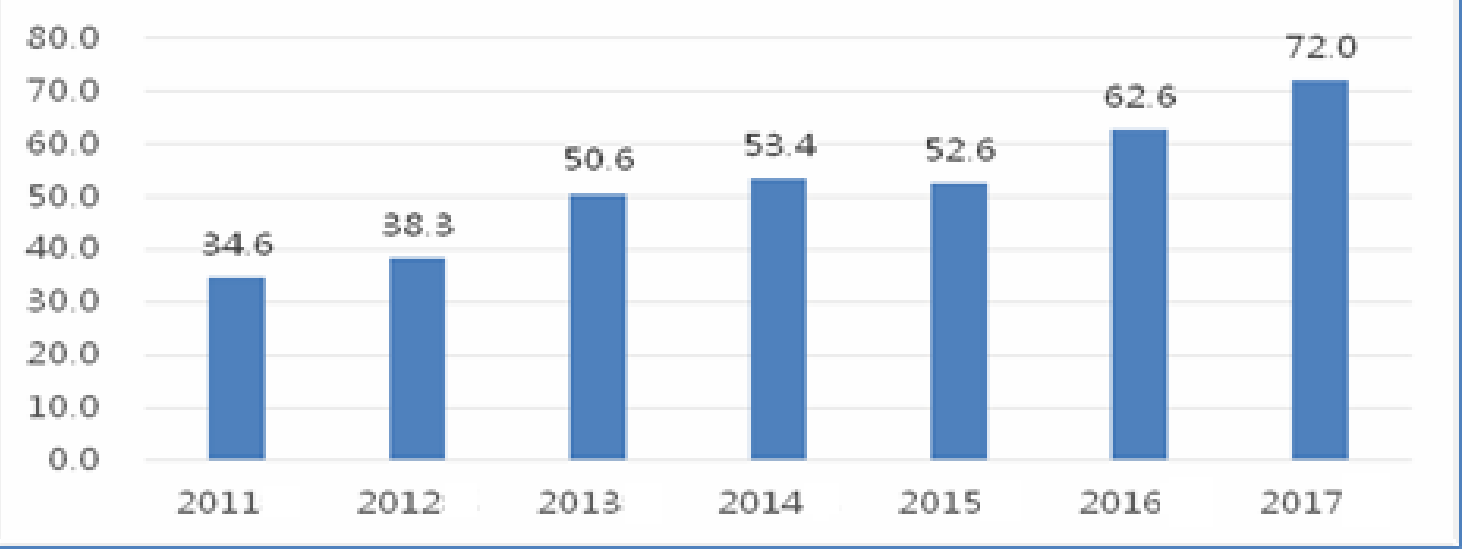

Source: MOFCOM, China

- China and the US are important investment partners.

China's deficit with the United States in the commercial enterprise continues to widen. In line with the DOC, by 2016 the amount of Chinese terra firm guests to the United States had been increasing for thirteen consecutive years, with double-digit growth in twelve of the thirteen years. MOFCOM statistics recommend that in 2017 Chinese guests planning to the United States for commercial enterprise, education, and medical treatment spent a complete of United States\$51 billion within the US. Among them, three million were tourists, World Health Organization spent the maximum amount as United States $\$ 33$ billion whereas traveling within the US. In education, the United States is the largest overseas destination for Chinese students. In 2017, there have been around 420,000 Chinese students within the United States, contributive some US\$18 billion to native revenues. inline with United States figures, China's deficit with the United States in commercial enterprise grew from US\$430 million in 2006 to US\$26.2 billion in a pair of 16 , registering a median annual growth of $50.8 \%$. China's payments for the employment people material possession continues to rise. Chinese statistics indicate that the United States is the largest supply of material possession imports to China. From 2012 to 2016, China foreign nearly 28,000 things of material possession from the United States. China's payments for United States material possession doubled in six years from US\$3.46 billion in 2011 to US\$7.2 billion in a pair of 017. (Figure-3) In breakdown, China's material possession payments to the United States accounted for $1 / 4$ of its total material possession payments to foreign countries.

- China and the U.S have each benefited markedly from trade and economic cooperation.

China and also the United States have each reaped huge edge and created win-win results from trade and economic cooperation. China-US trade and economic cooperation have promoted economic development in China and improved economic successfulness. Against the backcloth of economic globalization, strengthening trade and investment cooperation with alternative countries, together with the United States, and gap up markets to every alternative has helped Chinese enterprises integrate into the worldwide industrial chain and price chain, and displayed a large external marketplace for Chinese economic process. Due to economic development over the past forty years of reform and gap up, in 2017 China became the world's largest dealer in merchandise, with US\$4.1 trillion of total merchandise imports and exports. It became the second-largest dealer in services with US\$695.68 billion value of total services imports and exports. And it became the second-largest recipient of FDI, with US\$136 billion of inward foreign investment. Yankee corporations have contended associate exemplary role in China for 
his or her Chinese peers in terms of technological innovation, selling management, and institutional innovation. They need to promote market competition, improved business potency, and impelled Chinese corporations to enhance their technology and management. In commerce, an oversized variety of mechanical and electrical merchandise and agricultural merchandise from the United States, China has managed to form up for its own provide deficiencies, and satisfy the demand - especially high-end demand - in varied sectors by providing shoppers a diversity of alternative. At constant time, the United States has gained access to a good vary of business opportunities like cross-border investment and entry into the China market, that have contended a giant half in driving the economic process, up to client welfare, and upgrading the economic structure within the United States. Trade and economic cooperation have supported United States economic process and lowered United States inflation. A joint estimate by the United States-China Business Council and Oxford social science indicate that in 2015 imports from China drove up to the US gross domestic product by 0.8 proportion points. Exports to China and two-way investment contributed US\$216 Onion to America's value, pushing the United States economic process rate up by 1.2 proportion points. Value-for-money merchandise from China drove down costs for Yankee shoppers, and in 2015 for instance, reduced the patron indicant by one to 1.5 proportion points. An occasional inflation setting has created an abundant area for expansionary political economy policies within the United States. Trade and economic cooperation have created an oversized variety of jobs within the United States. In line with a US-China Business Council estimate, 2015, United States exports to China and US-China two-way investment supported a pair of of.6 million jobs in America. Specifically, Chinese investment lined forty-six states of the United States, generating for the United States quite 140,000 jobs, most of that is in producing. Trade and economic cooperation have brought real edges to Yankee shoppers. Bilateral trade provides shoppers with a broad vary of decisions, lowers their living prices, and raises the important buying power of the Yankee individuals, particularly the low- and middle-income cohort. in line with the US-China Business Council, in 2015, trade with China saved each Yankee family US\$850 of expenditure annually, that is corresponding to one.5\% of the common family financial gain within the United States. Trade and economic cooperation have created an oversized variety of business opportunities and important profits for Yankee businesses. With China being a large and speedily growing market, trade and economic cooperation between China and also the US has created Brobdingnagian business opportunities for American businesses. From the trade perspective, the US-China Business Council 2017 State Export Report found that in 2017, China was one among the highest Five export markets of products for forty-six states. In 2016 China was one among the highest five export markets of services for all fifty states. On average, each United States farmer exported over US\$10,000 of agricultural merchandise to China in 2017. From the investment perspective, in line with MOFCOM, in 2015 United States corporations in China accomplished close to US\$517 billion of sales revenue and over US\$36 billion of profits; in 2016, their sales reached regarding U5 $\$ 606.8$ billion and profits exceeded US\$39 billion. For the highest 3 United States automakers, their joint ventures in China created a complete profit of US\$7.44 billion in 2017. Within the same year, a corrected of three.04 million Yankee traveler vehicles were sold-out in China, accounting for twelve. $3 \%$ of all traveler vehicles sold-out in China. General Motors alone has 10 joint ventures in China. Its output in China accounted for fourhundredth of its world output. Qualcomm's financial gain from chip sales and patent royalties in China accounted for fifty-seven of its total retinue. Intel's revenues in China (including the urban center region) accounted for twenty-three.6\% of its total revenue. Within the FY 2017, revenues from larger China accounted for ningen.5\% of the Apple opposition. Total. By Gregorian calendar month 2017, thirteen Yankee banks had subsidiaries or branches and 10 Yankee insurance corporations had insurance corporations in China. Emma Goldman Sills, Yankee specific, Bank of America, Metlife and alternative Yankee money establishments have reaped handsomirturns from their strategic investment in Chinese money establishments. In line with China Securities regulative Commission, Yankee investment banks were lead underwriters or co-lead underwriters for seventieth of the funds raised by Chinese corporations in their overseas Iles and refinancing. United States law corporations have started regarding one hundred twenty offices in China

Trade and economic cooperation have promoted industrial upgrading. In flair trade and economic cooperation with China, United States international corporations have sharpened their international fight by combining competitive factors of production within the two countries. For instance, iPhones are designed within the United Sta $\mathrm{n}$ factory-made and assembled in China and sold-out within the world. In line with an Emma Goldman Sachs report in 2018, ought to Apple opposition. Relocate all its production and assembly to the United States, its product price 'would increase by thirty-seventh. In technological cooperation, United States corporations that have sales and investment in China fancy the advantages of cloud computing and computing applied in China, so Yankee merchandisgNill higher adapt to the dynamic world market. By producing for United States corporations, China has enabled the United States to speculate extra money and resources in innovation and management, specializing in high-end producing and fashionable services, and upgrade its business with additional added-value and engineering. This has conjointly helped the United States in protective energy and resources and mitigating pressure in environmental protection reception, creating the United States additional competitive within the world. In general, China-U. S trade and economic cooperation may be a win-win relationship and by no means that a 
game, conveyance concrete edges to United States corporations and folks. Some Americans claim that the US is "losing" during this relationship, a claim that doesn't get on my feet to scrutiny.

\section{Analysis and Recommendation}

The World Trade Organization principle of reciprocity takes into thought totally different development stages by granting special, differential and a lot of favorable treatment to developing members. This arrangement aims to draw in new developing members, increase the WTO's illustration and enhance the inclusiveness of the four-sided system, whereas respecting the correct to develop of developing countries and regions. It enshrines the principle of mutual profit in exchanging gift favors for future openings. Developing members that are within the initial stages of development would like capturable protection for his or her industries to push their sound growth, which can offer a lot of opportunities for developed countries in time. This differential and a lot of favorable treatment are within the long-run interests of all countries and regions, as well as developed members, and this can be real international fairness.

China, having consummated its World Trade Organization commitments, has voluntarily engaged in unilateral tariff reductions to expand the market gap. By 2010, all commitments in merchandise had been consummated, with the tariff level slashed from $15.3 \%$ in 2001 to 9.8 percent. Nonetheless, China failed to limit itself to World Trade Organization commitments; its promoted trade and investment liberalization through trade agreements, given special treatment in tariffs to the smallest amount developed countries and considerably reduced import tariffs victimization conditional tariffs on many occasions. The idea of "fair trade" and "reciprocal gap up" advocated by U.S.A. ignores the existence of objective variations among countries in terms of stages of development, resources and competitive industries, and ignores developing countries' right to develop. It'll produce an effect on the economy and industries of developing countries, lead to broader difference and eventually forestall U.S. businesses from increasing their international market share and sharing development opportunities in developing countries.

Since the adoption of reform and gap up, foreign enterprises have established partnerships with Chinese corporations by voluntarily going in contracts. Rey transferred production capability and orders to China of their own volition thus on faucet into the rising market, save production prices, accomplish an economy of scale and extend the term of benefiting from technologies. These are voluntary behaviors supported business interests. It accords with neither historical facts nor the spirit of the contract to unjustly label bilateral transactions on a voluntary basis as forced technology transfer merely on the grounds of Chinese firms' technological advances. Technology transfer within the course of cooperation between China and developed countries like the U. S. The merchandise life-cycle theory indicates that any quite product goes through a! if cycle from peak to say no because of the appliance of recent technologies. Whereas endeavoring to develop new technologies, multinationals unceasingly transfer technologies that are either obsolete or standardized to developing countries with a read to extending the term of benefiting from recent technologies, creating space and scotch production factors for analysis and development (R\&D) and also the application of recent ones, and indirectly sharing R\&D prices. Therefore, technology transfer and licensing are a widely used business cooperation model.

Since the 1990s, Microsoft, Intel, Qualcomm, Procter \& Gamble, GE, luminous and alternative U.S. corporations have found out R\&D facilities in China in an exceedingly bid to higher adapt to and explore the Chinese market. Over the years, U.S. companies in China have earned handsome profits through technology transfer and licensing. They're the biggest beneficiary of technological cooperation.

In the method of cooperation, the Chinese Government has ne'er introduced policies or practices that force foreign-invested enterprises to transfer technology. Technological cooperation and alternative styles of business cooperation between Chinese and foreign businesses are entirely voluntary and sure by contracts. It generates real edges for corporations on each side. China's angle toward IPR protection is evident and firm. It continuing to strengthen protection through legislation, enforcement and also the judiciary, and has achieved some notable successes. China has developed and improved its laws and rules on IPR protection and increased protection of IPR. China designed a fully-fledged and high-standard IPR legal framework in an exceedingly comparatively short amount, compared to the decades or a lot of that developed countries spent putting in place similar legal systems. China has placed in situ a whole regime of IPR protection, utilization and administration, spanning laws, planning, policies, and social control agencies. China has intense judicial protection for IPR and given full play to judicial protection. In 2014, China found out 31PR tribunals in the national capital, Shanghai and urban center to handle cross-regional IPR cases, as well as those associated with patents. Since 2009, China has established sixteen special judicial organs in Tientsin, Nanjing, Suzhou, and Wuhan, Xi'an and alternative cities, enhancing the skilled handling of IPR cases

IPR body authorities have taken protecting measures and intense social control in an exceedingly proactive manner. China adopts a dual-track protection system wherever IPR holders will look for not solely judicial however additionally body protection.

U.S. trades have promoted momentously from effective IPR shield in China. In keeping with the U.S. Bureau 
of Economic Analysis of the Department of Commerce (DOC), China paid \$7.96 billion in licensing fees to the U. S. in 2016. Statistics from China's National Copyright Administration, Ministry of Commerce and State Administration for Market Regulation counsel that from 2012 to 2016, China foreign 28,000 copyrights from the US. In terms of emblems, from gp0 2 to 2016, the U. S. applied for over 58,000 trademark transfers in China, creating up to four.54\% of total transfers. In terms of culture, in keeping with the note Administration of Press, Publication, Radio, Film, and TV, in 2017, China foreign thirty-one U.S. films at a price of $\$ 650$ million.It is per World Trade Organization rules for the Chinese Government to encourage businesses to travel international and interact in international economic,' exchanges and cooperation. As Chinese corporations get stronger and also, they would like for resource allocation and market enlargement will increase, a growing range of companies have begun to expand overseas on their initiative, a trend in line with economic with globalization system. Like alternative countries and regions within the world, the Chinese Government supports ready and competent corporations in outward-bound investment and in sound into international markets whereas obeying the laws and rules of the host countries also as international rules. The govt. solely provides services that facilitate this outwardbound investment and cooperation. The impulsive U.S. conclusion that such support may be a government act to amass advanced technologies through business M\&A is unsupported.

In fact, among Chinese investments within the Las., people who look for to amass technology represent a little share. In keeping with the yank Enterprise altitude, from 2005 to 2017, of 232 direct investments from China, solely seventeen concerned hi-tech; the others were principally in real estate, finance, and services.

China's grant policy complies with World Trade Organization rules and may not be attacked. Mutually of the tools to deal with market failure and unbalanced economic development, subsidies are wide employed by several countries and regions, as well as the U.S. Since China joined the World Trade Organization, it's actively ironed ahead with reform to make sure the compliance of domestic policies and carefully honored the obligations beneath the World Trade Organization Agreement on Subsidies and Countervailing Measures.

China complies with the World Trade Organization rules on grant transparency. As needed, China has frequently notified the World Trade Organization of the revision, adjustment, and implementation of its domestic laws, rules, and measures. At the beginning time of 2018, China had submitted many notifications, covering varied areas of central and sub-national grant policies, agriculture, technical rules, standards, and IPR laws and rules. In Gregorian calendar month 2016, in accordance with the relevant rules, the Chinese Government notified the World Trade Organization of sub-national grant policies between 2001 and 2014, covering one hundred grant policies from nineteen provinces and 3 municipalities with freelance coming up Oh authority. in Gregorian calendar month2018, China notified the World Trade Organization of the central and sub-national grant policies between 2015 and 2016, covering all the provincial-level body areas for the primary time.

\section{Conclusion and Critique}

The U.S. Government has taken extreme trade exponent measures, that have undermined the international economic order, caused harm to China-U.S. trade and trade relations around the world, noncontiguous the worldwide price chain and therefore the international division of labor, upset market expectations, and semiconductor diode to violent swings within the international monetary and goods markets. It's become the best supply of uncertainty and risk for the recovery of the worldwide economy. In advancing toward civilization, humanity has wide accepted a world governance system supported rules and quality. Countries, massive or little, sturdy or weak, ought to respect one another, have interaction in equal-footed dialogue and conjointly safeguard international rules within the spirit of the contract. This can be basic to promoting international trade and investment and boosting international growth. However, the recent steps were taken by the U.S. administration that are contrary and even damaging to the present three-sided trade rules seriously undermine the present international economic order. The U.S. administration has issued open criticism of the foundations and operation mechanism of the WTO on varied occasions. its refused to endorse the three-sided commerce system and at a similar time has adopted a negative angle toward international economic governance, that caused the failure of the APEC trade ministers' conferences, in each 2017 and 2018, to achieve accord on supporting the three-sided commerce system. Specifically, the U.S. administration's objection to writing "opposition to trade protectionism" into the ministers' statement was met with opposition from each alternative APEC member. The U.S. lashed out at the WTO proceeding body and repeatedly blocked the appointment procedures of the body, leading to an inadequate proceeding body and pushing the World Trade Organization dispute settlement mechanism to the brink of dis-function. As globalization moves forward, the economies of the planet are progressively connected through trade that has become a significant engine of worldwide growth. In line with the planet Bank, the international economy's dependence on trade rose from $17.5 \%$ in 1960 to $51.9 \%$ in 2017 . The international economy has simply emerged from the shadow of the 2008 global monetary crisis and therefore the recovery is nonetheless to be solid. During this context, the U.S. administration's actions to instigate life-scale trade frictions and impede the flow of world trade can doubtless have an effect on the recovery of the worldwide economy. So as to mitigate the exponent moves of the U.S., countries are left with no alternative however to require countermeasures. This may 
disrupt the planet economic and trade order and wait for international recovery, damaging the interests of firms and other people of all countries and pushing the worldwide economy back to recession. According to international Economic Prospects printed by the planet Bank on June five, 2018, a broad-based increase in tariffs worldwide can have major adverse consequences that might translate into a decline in international trade amounting to $9 \%$ by 2020 . The impact would be additional severe on rising markets and developing economies, significantly on those with giant trade or monetary market linkages with the U.S. in a deeply integrated international economy, countries type an extremely economical international price chain and share within the dividends of economic globalization through division of labor by harnessing their various strengths in technology, labor and capital. Companies, particularly transnational ones, minimize their product prices and lift the standard of their merchandise and services through the international allocation of resources, so achieving a win-win result for themselves and for customers.

By raising tariffs and building trade barriers, the U.S. administration has angry trade frictions worldwide. U.S. transnational companies are being vulnerable with the "traitor" label and retributive taxes if they are doing not move their operations back to the U.S. Such moves can seriously undermine or maybe break the worldwide price chain, and jeopardize the conventional flow of trade and resource allocation across the planet. Since of the interconnections between countries through trade and economic links, they're going to additionally turn out indepth spillovers and scale back the potency of the worldwide economy. As an example, the auto, physical science, and craft sectors, among others, are all supported by advanced, huge industrial chains. Economies on the provision chain, as well as Japan, the EU and therefore the Republic of the peninsula, can all be adversely stricken by catching trade. Even U.S. suppliers won't be immune from the next ripple result.

to economic globalization, economies, significantly the larger ones, are extremely mutually beneficial. Ultimately, the trade wars unilaterally initiated by the U.S. administration won't solely hurt alternative economies however additionally undermine U.S. interests. MIT will push up producing prices and have an effect on U.S, jobs. A Peterson Institute for International social science report contends that since 95\% of the Chinese merchandise hit by higher tariffs are components and electronic parts employed in finish merchandise created within the U.S, raising tariffs on these Chinese merchandises can solely harm U.S. businesses. It will draw near costs within the U.S and hurt customers. Goods account for a substantial share of U.S. imports from China. The figure (excluding food and automobiles) stood at $46.6 \%$ in 2017 , in line with the U.S. Department of Commerce's Bureau of Economic Analysis. For several years, the import of cheap nonetheless quality merchandise from China has been key to the low inflation within the U.S.

It triggers countermeasures from commerce partners and can successively hurt the U.S. economy. The trade war waged by the U.S. administrator against China and plenty of alternative vital commerce partners has semiconductor diode to countermeasures and can cause immense losses to some regions, industries, and companies within the U.S. As of the top of July 2018, major U.S. commerce partners, as well as China, Canada, Mexico, Russia, the EU, and Turkey, had all declared countermeasures against U.S. trade economic policy and had filed lawsuits with the WTO. The U.S. Chamber of Commerce has noted that a trade war can hit some U.S. states. As an example, American state might see $\$ 3.9$ billion prices of exports targeted by retributory tariffs, south geographic region, $\$ 3$ billion, and Tennessee, $\$ 1.4$ billion. It erodes investors' confidence within the U.S. economic setting and ends up in less internet foreign direct investment into the U.S. As trade frictions increase, firms feel less assured and additional hesitant regarding investment.

\section{References}

Bown, C. P. (2009). US-China Trade Conflicts and the Future of the WTO. Fletcher F. World Aff., 33, 27.

Bown, C. P., \& McCulloch, R. (2009). US-Japan and US-China trade conflict: Export growth, reciprocity, and the international trading system. The World Bank.

David, H., Dorn, D., 8t Hanson, G. H. (2013). The China syndrome: Local labor market effects of import competition in the United States. American Economic Review, 103(6), 2121-68.

Friedberg, A. L. (2005). The future of US-China relations: Is conflict inevitable? International security, 30(2), 745.

Ferrantino, M. J., Liu, X., \& Wang, Z. (2012). Evasion behaviors of exporters and importers: Evidence from the US-China trade data discrepancy. Journal of international Economics, 86(1), 141-157.

Guobing, S. (2005). Trade Statistical Discrepancies and US-China Trade Balance Issues [J]. Economic Research Journal, 6 .

Feenstra, R., Hai, W., Woo, W., \& Yao, S. (1998). The US-China Bilateral Trade Balance: Its Size and Determinants. National Bureau Of Economic Research Working Paper Series. Retrieved from https://www.nber.org/papers/w6598

Glaser, B., \& Billingsley, B. (2011). US-China Relations: Friction and Cooperation Co-exist Uneasily. Comparative Connections, 13(2), 27.

Glaser, B., \& Billingsley, B. (2011). US-China relations: US pivot to Asia leaves China off balance. Comparative 
Connections, 13(3), 29.

Johnson, R. C. (2014). Five facts about value-added exports and implications for macroeconomics and trade research. Journal of Economic Perspectives, 28(2), 119-42.

Kim, S. H., Martin-Hermosillo, M., \& Jia, J. (2014). The US-China Trade Friction: Causes and Proposed Solutions. Journal of Applied Business \& Economics, 16(5).

Li, C., Wang, J., \& Whalley, J. (2017). China's regional and bilateral trade agreements. In THE ECONOMIES OF CHINA AND INDIA Cooperation and Conflict: Volume 1: China and India-The International Context and Economic Growth, Manufacturing Performance and Rural Development (pp. 175-194).

Morrison, W. M. (2011). China-US trade issues.

Manyin, M. E. (2006, February). South Korea-US Economic Relations: Cooperation, Friction, and Prospects for a Free Trade Agreement (FTA). Congressional Research Service, Library of Congress.

Snyder, S., \& Byun, S. W. (2010). China-ROK Trade Disputes and Implications for Managing Security Relations. Korean Economic Institute Academic Paper Series, 5(8).

Woo, W. T. (2008). Understanding the sources of friction in US - China trade relations: The exchange rate debate diverts attention from optimum adjustment. Asian Economic Papers, 7(3), 61-95.

Zhao, H. (1987). Foreign trade in the People's Republic of China: past performance and future challenges.

Zhu-ying, F. Q. Z. (2008). Empirical Study on the Impact of US FDI on China-US Bilateral Trade Imbalances [J]. Journal of International Trade, 7.

UNCTADstat - General Profile: United Kingdom. (2019). UNCTADstat. Retrieved 9 July 2019, from https://unctadstat.unctad.org/countryprofile/generalprofile/en-gb/926/index.html

UNCTADstat - General Profile: China. (2019). UNCTADstat. Retrieved 9 July 2019, from https://unctadstat.unctad.org/countryprofile/generalprofile/en-gb/156/index.html

UNCTADstat - Table view. (2019). Unctadstat.unctad.org. Retrieved 9 July 2019, from https://unctadstat.unctad.org/wds/TableViewer/tableView.aspx?ReportId=100

(2019). Unctad.org. Retrieved 9 July 2019, from https://unctad.org/en/PublicationsLibrary/tdr2018 en.pdf

China | Data. (2019). Data.worldbank.org. Retrieved 9 Imports of goods and services (\% of GDP)| Data. (2019). Data.worldbank.org. Retrieved 9 July 2019, from https://data.worldbank.org/indicator/ne.imp.gnfs.zs July 2019, from https://data.worldbank.org/country/china

The People's Republic of China. (2019). Ustr.gov. Retrieved 9 July 2019, from https://ustr.gov/countriesregions/china-mongolia-taiwan/peoples-republic-china

China | Exports and Imports | by Country 2017 | WITS | Data . (2019). Wits.worldbank.org. Retrieved 9 July 2019 , from https://wits.worldbank.org/CountryProfile/en/Country/CHN/Year/2017/TradeFlow/EXPIMP/Partner/bycountry

Anon (2019). Fas.org. Retrieved 9 July 2019, from https://fas.org/sgp/crs/row/IF10030.pdf

World Development Indicators (WDI) | Data Catalog. (2019). Datacatalog.worldbank.org. Retrieved 9 July 2019, from https://datacatalog.worldbank.org/dataset/world-development-indicators

U.S. Bureau of Economic Analysis (BEA). (2019). Bea.gov. Retrieved 9 July 2019, from https://www.bea.gov/

MINISTRY OF COMMERCE, PEOPLE'S REPUBLIC OF CHINA. (2019). English.mofcom.gov.cn. Retrieved 9 July 2019, from http://english.mofcom.gov.cn/ 